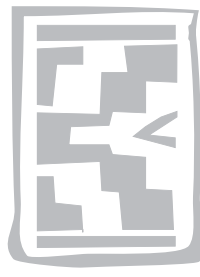

\title{
Seroprevalence of Toxoplasma gondii infection in domestic pigs reared under different management systems in Zimbabwe
}

\author{
T. HOVE ${ }^{1 *}$, P. LIND² and S. MUKARATIRWA ${ }^{1}$
}

\begin{abstract}
HOVE, T., LIND, P. \& MUKARATIRWA, S. 2005. Seroprevalence of Toxoplasma gondii infection in domestic pigs reared under different management systems in Zimbabwe. Onderstepoort Journal of Veterinary Research, 72:231-237

Serum samples from 474 domestic pigs (Sus scrofa) from Zimbabwe were tested for anti-Toxoplasma gondii IgG antibodies using the indirect fluorescent antibody test. The results showed that $T$. gondii infection is widespread in Zimbabwean pigs. Seroprevalence was lowest in fattening pigs from large and small-scale commercial farms that practise good hygiene $(19.75 \%$ of 238 ) and highest in backyard scavenging pigs (35.71\% of 70 ). Only $11.7 \%(11)$ of the 127 positive samples had titres of $\geq 1: 400$ and nine $(81.82 \%)$ of these 11 originated from pigs reared under poor hygienic conditions. A prevalence of $3.51 \%$ was found in the same group of fattening pigs using an indirect lgG enzyme-linked immunosorbent assay at the single serum dilution of 1:400. The serosurvey shows the importance of modern intensive husbandry systems in reducing the prevalences of $T$. gondii infection in domestic pigs.
\end{abstract}

Keywords: Domestic pigs, IFAT, IgG antibodies, public health implications, Toxoplasma gondii, Zimbabwe

\section{INTRODUCTION}

Zimbabwe has 139867 pigs in communal land farming areas (Central Statistical Office 1999) and 97996 on commercial farms (Central Statistical Office 2002). Commercially reared pigs are kept in pens with concrete floors, in total confinement (without access to other animals including cats and small rodents), under good hygienic conditions and are fed large amounts of grain and supplied with

* Author to whom correspondence is to be directed. E-mail: thove@vet.uz.ac.zw

1 Parasitology Section, Department of Paraclinical Veterinary Studies, Faculty of Veterinary Science, University of Zimbabwe, P.O. Box MP167, Mount Pleasant, Harare, Zimbabwe

2 Danish Institute for Food and Veterinary Research, 27, Bülowsvej, DK-1790 Copenhagen V, Denmark

Accepted for publication 6 June 2005-Editor adequate drinking water. Backyard pigs scavenge around the homes and crop fields during the dry season, are fed crop residues and household waste when available and have very little drinking water. Their housing and hygiene is generally poor. Domestic pig breeds kept on commercial farms are mainly Large White, Landrace and their crosses, while backyard pigs are mainly the indigenous Mukota and its crosses. Research stations such as those of the University of Zimbabwe farm and the Pig Industry Board of Zimbabwe also keep the Mukota besides the exotic breeds.

Undercooked pork is considered an important source of Toxoplasma gondii infection for humans in the USA (Dubey, Leighty, Beal, Anderson, Andrews \& Thulliez 1991). The prevalence of antibodies against $T$. gondii in domestic swine of various categories on large commercial farms in developed countries has declined over the years due to 
improvement in managemental practices (Van Knapen, Franchimont \& Van der Lugt 1982; Dubey 1990; Edelhofer 1994; Van Knapen, Kremers, Franchimont \& Narucka 1995; Davies, Morrow, Deen, Gamble \& Patton 1998) but pockets of high seroprevalence are still found on some small farms (Dubey, Gamble, Hill, Romand \& Thulliez 2002). In sub-Saharan African countries, there are very few reports on the seroprevalence of $T$. gondii in domestic pigs (Dubey \& Beattie 1988; Pandey \& Van Knapen 1992; Hove \& Dubey 1999; Arko-Mensah, Bosompem, Canacoo, Wastling \& Akanmori 2000). Most of the pigs in these countries are likely to be kept on small farms where managemental practices are not that stringent, thus increasing their chances of infection with Toxoplasma.

The objective of the present study was to determine the seroprevalence of anti- $T$. gondii specific IgG antibodies in domestic pigs from different managemental systems.

\section{MATERIALS AND METHODS}

\section{Sampling sites}

Samples were randomly collected from three abattoirs and selected villages. The sampling sites are shown in Fig. 1.

\section{Abattoirs I and II}

A total of 238 serum samples were collected from randomly selected fattening pigs from Abattoirs I (138) and II (100) during 2000 and 2001. These two abattoirs are Grade A abattoirs that maintain very high hygienic standards and are designated for the slaughter of pigs destined for the European market. The animals they target originate from large and small commercial producers that keep pigs indoors and practice intensive husbandry. The inspection of carcasses is done by staff from the Department of Veterinary Services. Abattoir I is situated in the city of Bulawayo and slaughters pigs from the dry southern part of the country whilst Abattoir II is in Harare and its catchment areas are the farms in the wetter northern region of Zimbabwe. Fattening pigs are slaughtered between 3 and 6 months of age. Fifty five samples were also collected from culled, adult pigs between 4 and 5 years of age at Abattoir II during November and December 2002.

\section{Abattoir III}

One hundred and eleven samples were collected from Abattoir III in September 2002. Abattoir III is a
Grade B abattoir located in Bulawayo in which a variety of livestock species are slaughtered, irrespective of their origin. Its catchment area is mainly the small producers who practise extensive husbandry at some point in the life cycle of the pig and are unable to meet inspection standards of the Grade $A$ abattoirs. The breeds slaughtered range from the exotic to the indigenous. Records on the age and origin of animals are usually unavailable. Systematic meat inspections are rarely done.

\section{Communal land farming areas}

Seventy samples were collected during September 2002 to March 2000 from villages in the following communal land districts that keep a large number of backyard, scavenging pigs: Mbembesi and Ntabazinduna (south-west), and Mt. Darwin (north-east).

\section{Blood collection and separation of sera}

In the abattoirs, blood from each animal was collected into sterile universal bottles at the time of slaughter or on-farm from the jugular vein. The clotted blood samples were centrifuged in a bench centrifuge (MSE Centaur 2, MSE Scientific Instruments) at $2500 \mathrm{rpm}$ for $5 \mathrm{~min}$ and the sera collected and kept at $-20^{\circ} \mathrm{C}$ until tested.

\section{Immunoassays}

\section{Indirect enzyme-linked immunosorbent assay}

The presence of specific $\lg G$ antibodies to $T$. gondii in fattening pigs was determined by the indirect enzyme-linked immunosorbent assay (indirect ELISA) (Lind, Haugegaard, Wingstrand \& Henriksen 1997). Ninety-six-well, polystyrene flat-bottomed microtitre plates (Nunc, Polysorp) were coated with T. gondii RH strain (Sabin 1941) tachyzoite lysate antigen (Tx-12) diluted at 1:2000 and kept overnight at $4{ }^{\circ} \mathrm{C}$. The next day, before use, excess antigen was washed off in three cycles with $0.01 \mathrm{M}$ PBS (pH 7.4) containing $0.1 \%$ Tween-20 (PBS-T). Test sera were diluted at 1:400 in PBS-T and added to the washed plates after which the plates were incubated at room temperature on a shaker for $1 \mathrm{~h}$. After incubation, the plates were washed with PBS-T in three cycles. Horse radish peroxidase (HRP)-labeled goat anti-swine serum with $1 \%$ of normal goat serum was added to the plates and incubated for another hour, after which the plates were washed as before. O-phenylenediamine (OPD)-substrate was added to each well followed by 10 min incubation in the dark at room temperature. The reaction was 
stopped by addition of an equal volume of $0.5 \mathrm{M}$ $\mathrm{H}_{2} \mathrm{SO}_{4}$ to each well.

Each serum sample was tested in duplicate. Plates were read by measuring optical density (OD) at 490 $\mathrm{nm}$ on a dual-beam Vmax ${ }^{\circledR}$ kinetic microplate spectrophotometer (Molecular Devices, Palo Alto, California), automatically subtracting the reference absorbance at $650 \mathrm{~nm}$. The SOFTmax® PRO 4.0 microplate data acquisition and analysis software was used (Molecular Devices, Palo Alto, California). An OD of 0.36 was considered as the cut-off point. Optical density values were corrected for plate-toplate variation by linear regression of the OD values of a series of standard positive and negative sera on each plate against the mean OD value of the standard sera of all the plates in the experiment.

\section{Indirect fluorescent antibody test (IFAT)}

Whole T. gondii parasites of the Danish reference strain SSI 119 (Work 1968; Pettersen 1977) grown in bovine turbinate cells were used as antigen (Jensen, Petersen, Henriksen, Dietz \& Lind 1998). Eighteen-well glass microscope slides (Immuno-cell International) were coated with cell culture supernatants of $T$. gondii (concentration: $2 \times 10^{6}$ parasites $/ \mathrm{m} \ell$ ) to form a single layer of parasites. Dried slides were fixed in $5 \%$ acetone, air dried and stored at $-20^{\circ} \mathrm{C}$ until used. The slides were thawed at room temperature for $30 \mathrm{~min}$ before use.

Serum samples were diluted 1:100, 1:200 and 1:400 in $0.01 \mathrm{M}$ PBS $(\mathrm{pH} 7.2)$ with $0.2 \%$ bovine fraction Valbumin (Sigma Chemicals). Antigen slides were incubated with $20 \mu \ell$ of test serum for $45 \mathrm{~min}$ at room temperature in a moist chamber. After incubation, the slides were washed three times, each for 5 min, in $0.01 \mathrm{M}$ PBS and air-dried. Each well was covered with $10 \mu \ell$ of fluorescein isothiocyanate (FITC)-conjugated with the rabbit anti-swine IgG (Sigma Chemicals), at a dilution of 1:40, incorporating $0.01 \%$ Evans Blue dye. After incubation for another $45 \mathrm{~min}$ at room temperature, slides were washed three times, each for $10 \mathrm{~min}$, in $0.01 \mathrm{M}$ PBS and mounted in $10 \%$ buffered glycerol. Positive and negative controls were included on each slide. Fluorescence at a serum dilution of $\geq 1: 100$ was considered positive. Positive sera produced complete bright fluorescence around the periphery of the parasite. Polar staining of the parasite membrane and dull/weak staining were considered as negative.

Each sample was tested in duplicate. Optimum concentration of the secondary antibody and the serum cut-off titre were determined by back titration with known negative and positive sera. Mounted slides were examined under a fluorescent microscope (Leitz Laborlux). Antibody titres were expressed as a reciprocal of the serum dilution.

\section{Statistical analysis}

Seroprevalence rates for the different categories of pigs were compared using the chi-square test. A probability $(P)$ value of $<0.05$ was considered significant.

\section{RESULTS}

The sera from the fattening pigs were screened with both tests. In the indirect ELISA, the serum samples were only screened at a single dilution of 1:400 whilst in the IFAT samples were screened at dilutions of $1: 100,1: 200$ and 1:400. Only 228 and 238 sera from intensively-raised fattening pigs were tested for anti-T. gondii antibodies using both the indirect ELISA and the IFAT respectively. Of these, $3.51 \%(8 / 228)$ and $19.75 \%(47 / 238)$ tested positive in the ELISA and the IFAT, respectively. The eight samples that tested positive in the ELISA were also positive in the IFAT. Using the IFAT, seroprevalences in fattening pigs for the southern region and the northern region were $18.11 \%(25 / 138)$ and $22 \%$ $(22 / 100)$ respectively (see Table 1$)$. The 55 adult pigs had a seroprevalence rate of $30.91 \%$ in the IFAT (Table 2). Only two of the 47 fattening pigs positive in the IFAT had antibody titres of $\geq 1: 400$, but none of the adult pigs had an antibody titre $>$ 1:100 (Table 4).

Seroprevalence in the sera collected from Abattoir III was $34.23 \%(38 / 111)$ and the majority (33/38) of these positive animals had anti-Toxoplasma antibody titres below 1:400.

Twenty-five (35.71\%) of the 70 backyard pigs tested were seropositive for Toxoplasma, the highest seroprevalence of $58.33 \%(7 / 12)$ being in those from Mbembesi district (Table 3). Only $16 \%$ (4) of the seropositive backyard pigs had antibody titres $\geq 1: 400$.

The highest seroprevalence $(35.71 \%)$ among the pigs tested was found in backyard herds followed by that in pigs from Abattoir III (34.2\%) whilst the lowest occurred in the fattening pigs (19.75\%) and seroprevalence in pigs from Abattoir III was very similar to that in backyard pigs. The majority of the positive samples $(70.07 \%)$ had antibody titres of 1:100 and comparatively more seroreactors from 
Seroprevalence of Toxoplasma gondii infection in domestic pigs in Zimbabwe

TABLE 1 Prevalence of anti-Toxoplasma gondii IFAT IgG antibodies in fattening pigs from commercial farms

\begin{tabular}{|c|c|c|c|c|}
\hline Region & Production system & Province & Number of samples & Positives (\%) \\
\hline Southern & $\begin{array}{l}\text { large scale } \\
\text { small scale } \\
\text { small scale } \\
\text { small scale }\end{array}$ & $\begin{array}{l}\text { Bulawayo } \\
\text { Matebeleland north } \\
\text { Matebeleland south } \\
\text { Masvingo/Midlands }\end{array}$ & $\begin{array}{l}57 \\
16 \\
38 \\
27\end{array}$ & $\begin{aligned} 12 & (21.0) \\
3 & (18.75) \\
8 & (21.05) \\
2 & (7.4)\end{aligned}$ \\
\hline \multicolumn{3}{|c|}{ Southern region subtotal } & 138 & $25(18.11)$ \\
\hline Northern & $\begin{array}{l}\text { large scale } \\
\text { large scale } \\
\text { large scale }\end{array}$ & $\begin{array}{l}\text { Harare } \\
\text { Mashonaland West } \\
\text { Mashonaland Central }\end{array}$ & $\begin{array}{l}48 \\
12 \\
40\end{array}$ & $\begin{aligned} 10 & (20.83) \\
1 & (8.33) \\
11 & (27.5)\end{aligned}$ \\
\hline \multicolumn{3}{|c|}{ Northern region subtotal } & 100 & $22(22)$ \\
\hline \multicolumn{3}{|l|}{ Total } & 238 & 47 (19.8) \\
\hline
\end{tabular}

TABLE 2 Prevalence of anti-Toxoplasma gondii IgG IFAT antibodies in culled adult pigs ( $\geq 4$ years old) from commercial farms

\begin{tabular}{|l|l|l|}
\hline Property & No. of pigs tested & Positives (\%) \\
\hline Farm K & 20 & $7(35)$ \\
Farm Q* & 15 & $3(20)$ \\
Farm L & 10 & $4(40)$ \\
Farm R & 10 & $3(30)$ \\
\hline Total & 55 & $17(30.9)$ \\
\hline
\end{tabular}

* Pigs from this farm are the indigenous Mukota breed whereas the exotic breeds mentioned are kept on the other farms

TABLE 3 Prevalence of Toxoplasma gondii IgG IFAT antibodies in pigs from abattoir III and from backyard herds

\begin{tabular}{|l|l|l|l|}
\hline Category & District & Number of pigs tested & Positives (\%) \\
\hline Unspecified (subtotal) & Abattoir III & 111 & $38(34.23)$ \\
\hline Backyard & Ntabazinduna & 26 & $6(23.1)$ \\
Backyard & Mbembesi & 12 & $7(58.3)$ \\
Backyard & Mt. Darwin & 32 & $12(37.5)$ \\
\hline Backyard (subtotal) & 70 & $25(35.7)$ \\
\hline
\end{tabular}

TABLE 4 Distribution of the Toxoplasma gondii seropositive pigs according to antibody titre

\begin{tabular}{|c|c|c|c|c|c|}
\hline \multirow{3}{*}{ Origin } & \multirow{3}{*}{ Category } & \multirow{3}{*}{ Positives } & \multicolumn{3}{|c|}{ Antibody titre* } \\
\hline & & & 100 & 200 & $\geq 400$ \\
\hline & & & \multicolumn{3}{|c|}{ Subtotal (\%) } \\
\hline Abattoirs I \& II & Fattening pigs & 47 & 35 (74.5) & $10(21.3)$ & $2(4.3)$ \\
\hline Abattoir II & Adult pigs & 17 & $17(100)$ & $0(0)$ & $0(0)$ \\
\hline Abattoir III & Unspecified & 38 & $23(60.5)$ & $10(26.3)$ & $5(13.2)$ \\
\hline Villages & Backyard & 25 & $14(56)$ & 7 (28) & $4(16)$ \\
\hline \multicolumn{2}{|c|}{ Total prevalence } & 127 (26.5\%) & 89 (70.1) & 27 (21.3) & $11(8.7)$ \\
\hline
\end{tabular}

* The antibody titre is expressed as a reciprocal of the serum dilution 


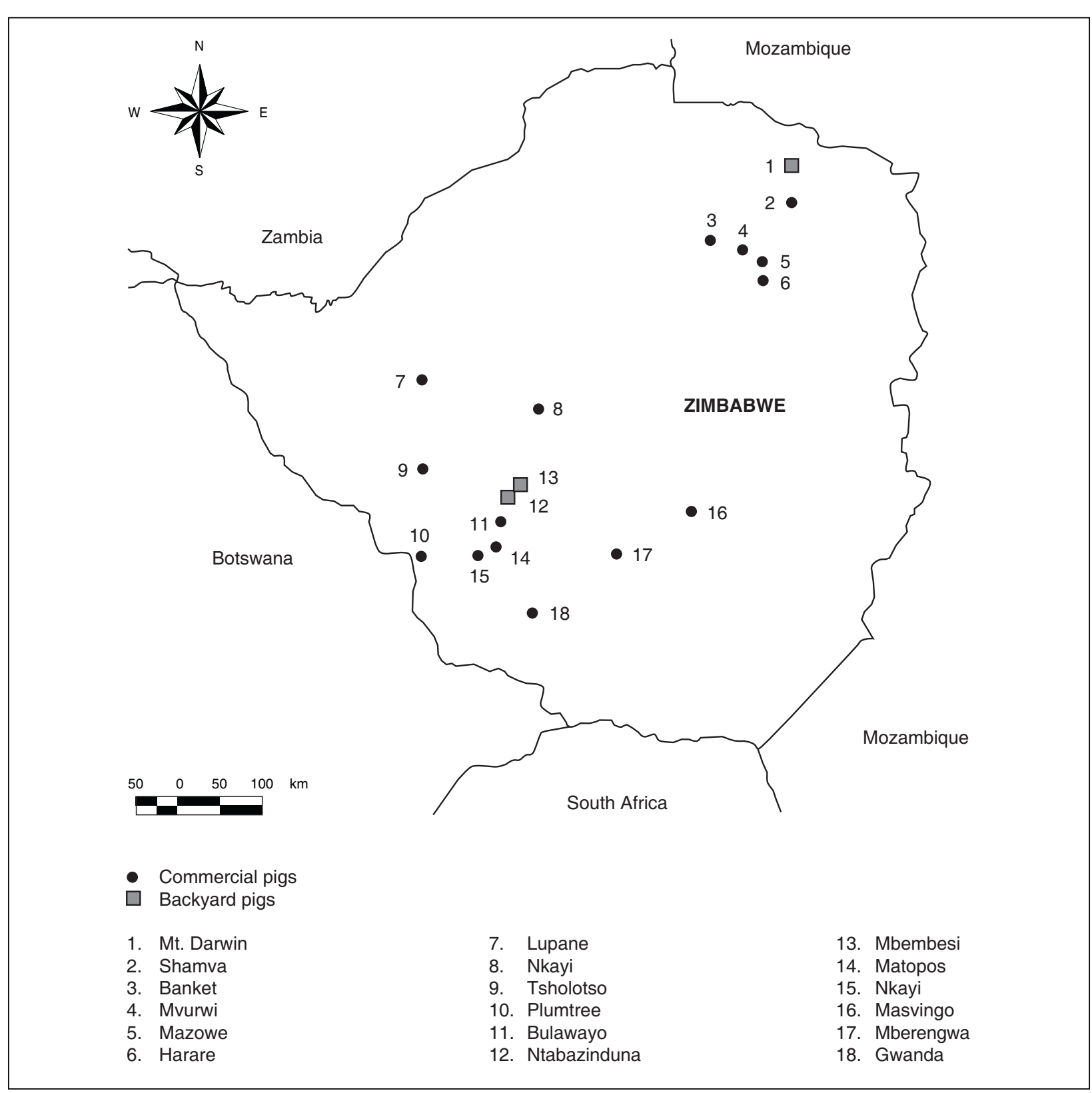

FIG. 1 Map of Zimbabwe showing the centres of the districts from where the pigs sampled originated

Abattoir III (13.2\%) and backyard herds (16\%) than from commercial properties (fattening pigs: $4.3 \%$; adult pigs: $0 \%$ ) had titres $\geq 1: 400$.

The comparison of seroprevalence rates among the different categories varied depending on the categories concerned and so did a comparison of the number of positive animals at each individual antibody titre $(1: 100,1: 200$ and $\geq 1: 400)$ either overall or among categories. Chi-square tests of the combined antibody positive samples by individual titre showed significant differences in the proportion of positives at all possible titre comparisons: 100 vs. $200\left(\chi^{2}=33.14, P<0.001\right), 100$ vs. $400\left(\chi^{2}=60.84\right.$, $P<0.001)$ and 200 vs. $400\left(\chi^{2}=6.74, P=0.01\right)$.

\section{DISCUSSION}

The indirect ELISA test was used initially to screen some of the swine sera whilst in Denmark. Due to the unavailability of an ELISA reader, the same test could not be used in Zimbabwe and it was replaced by the IFAT.

The low antibody prevalence (3.51\%) obtained with the indirect ELISA in commercially-reared market 
pigs is comparable to that found in the same category of pigs in developed countries such as Denmark (3.1\%) (Lind, Haugegaard, Heisel, Wingstrand \& Henriksen 1994) and Sweden (3.3\%) (Lundén, Lind, Olsson-Engval, Gustavsson, Uggla \& Vågsholm 2002) that use the same screening method. The large differences in seropositivity for the ELISA $(3.5 \%)$ and IFAT $(19.8 \%)$ in fattening pigs in this study is partly due to the fact that in the former test the samples were only screened at the single dilution of 1:400, whilst in the IFAT the samples were screened at dilutions of 1:100, 1:200 and 1:400. Only two of the 47 samples that tested positive in the IFAT had titres of $\geq 1: 400$. The differences in antibody titres in most of the samples that tested positive with both immunoassays (6/8) (data not shown) are most probably because the IFAT uses intact organisms as antigen and therefore measures antibodies to surface antigen epitopes only, whilst the ELISA uses parasite lysates as antigen and therefore measures antibodies to total parasite antigens (Parmely, Sgarlato, Mark, Prince \& Remington 1992). Wingstrand, Lind, Haugegaard, Henriksen, Bille-Hansen \& Sørensen (1997) also observed that at the chosen cut-off OD value of 0.36 , at the serum dilution of $1: 400$, in the IgG ELISA was able to detect 39 of 41 pigs that harboured viable parasites in their organs and were positive on bioassay in mice.

In the current study, the $19.8 \%$ T. gondii seroprevalence in the commercially-reared fattening pigs, aged between 4 and 6 months, with the IFAT was higher than the $9.3 \%$ seroprevalence obtained by Hove \& Dubey (1999) in the same category of pigs using the MAT. Dubey et al. (1991) found a national seroprevalence of $23.9 \%$ in market pigs in the USA using the MAT, whilst Arko-Mensah et al. (2000) found a seroprevalence of $36.4 \%$ in 6 to 12 month-old pigs in Ghana using a microplate ELISA, although the management systems under which the Ghanaian pigs were kept were not specified. In the present study, there was no significant difference $\left(\chi^{2}=0.17,=0.68\right)$ in seropositivity in fattening pigs from the northern region (18.84\%) and those from the southern region $(21 \%)$ of Zimbabwe. Within the group of pigs from commercial farms, the higher seroprevalence in adult pigs than that in market pigs agrees with findings from elsewhere in the world (Dubey et al. 1991; Arko-Mensah et al. 2000; Lundén et al. 2002) though there was no significant difference in seropositivity between the two categories $\left(\chi^{2}=3.26, P=0.07\right)$. Market pigs in Zimbabwe are slaughtered at 3-4 months of age (porkers) or at 6 months (baconers) whereas adult pigs are culled when about 4 years or more. The latter group therefore have a greater chance of exposure to $T$. gondii infection.

The higher seroprevalence in backyard pigs than in fattening and adult pigs reared in total confinement found in this study is similar to that found in the USA (Lubroth, Dreesen \& Ridenhour 1983; Dubey, Gamble, Rodrigues \& Thulliez 1992; Smith, Zimmerman, Patton, Beran \& Hill 1992). Seroprevalence in backyard pigs was significantly higher than that in adult pigs reared in total confinement $\left(\chi^{2}=41.16, P<\right.$ 0.001 ). Toxoplasma antibody prevalence in pigs from Abattoir III (Grade B) was not significantly different from that in the backyard indigenous pigs $\left(\chi^{2}=0.04, P=0.84\right)$ but was significantly higher than that of fattening and adult pigs (combined) slaughtered in the Grade A abattoirs $\left(\chi^{2}=6.55, P=\right.$ 0.01 ). The high level of antibodies against $T$. gondii in pigs slaughtered at Abattoir III indicates the unselective nature the establishment has when acquiring animals for slaughter whereby most of its throughput is likely to originate from badly managed farms that do not meet the requirements for the Grade A abattoirs. Although it has been shown that maintaining pigs outdoors was not always associated with a higher seroprevalence (Weigel, Dubey, Siegel, Kitron, Mannelli, Mitchell, Mateus-Pinilla, Thulliez, Shen, Kwok \& Todd 1995; Dubey, Rollor, Smith, Kwok \& Thulliez 1997), it might increase the risk of infection by accidental ingestion of cat faeces with oocysts and small rodents harbouring tissue cysts. Cats, particularly juveniles, and house mice have been identified elsewhere as indicators of increased risk of transmission for T. gondii (Weigel et al. 1995).

It has been demonstrated elsewhere that the chance of isolation of viable $T$. gondii parasites increases in proportion to increasing antibody titres in the pig (Dubey, Thulliez \& Powell 1995). If that is the case, the chances of acquiring T. gondii from pigs in Zimbabwe are more likely if one ingests undercooked pork from Abattoir III and from backyard pigs, and least likely if one ingests undercooked pork from adult pigs kept in confinement because it is under the first two categories that most of the pigs with high titres were found (Table 4). The antibody titres in adult pigs kept in confinement screened in this study were $\leq 1: 100$ in all animals tested.

\section{ACKNOWLEDGEMENTS}

The International Foundation for Science (project no. B/2855-1) and the European Union funded the 
work. The assistance of staff at the Colcom Abattoirs in Harare and Bulawayo with the collection of samples from commercially-reared pigs is appreciated. Dr Elizabeth Matenga is thanked for providing the sera from the backyard pigs. The Danish Institute for Food and Veterinary Research and the Central Veterinary Laboratory in Harare are thanked for technical support in the preparation of the antigens.

\section{REFERENCES}

ARKO-MENSAH, J., BOSOMPEM, K.M., CANACOO, E.A., WASTLING, J.M. \& AKANMORI, B.D. 2000. The seroprevalence of toxoplasmosis in pigs in Ghana. Acta Tropica, 76: 27-31.

CENTRAL STATISTICAL OFFICE REPORT, ZIMBABWE. 1999. Agriculture and livestock survey in communal lands.

CENTRAL STATISTICAL OFFICE REPORT, ZIMBABWE. 2002. Livestock on large scale commercial farms.

DAVIES, P.R., MORROW, W.E.M., DEEN, J., GAMBLE, H.R. \& PATTON, S. 1998. Seroprevalence of Toxoplasma gondii and Trichinella spiralis in finishing swine raised in different production systems in North Carolina, USA. Preventive Veterinary Medicine, 36:67-76.

DUBEY, J.P. 1990. Status of toxoplasmosis in pigs in the United States. Journal of the American Veterinary Medical Association, 196:270-274.

DUBEY, J.P. \& BEATTIE, C.P. 1988. Toxoplasmosis of animals and $\operatorname{man}, 1^{\text {st }}$ ed. Boca Raton: CRC Press.

DUBEY, J.P., GAMBLE, H.R., HILL, D., ROMAND, S. \& THULLIEZ, P. 2002. High prevalence of viable Toxoplasma gondii infection in market weight pigs from a farm in Massachusetts. Journal of Parasitology, 88:1234-1238.

DUBEY, J.P., GAMBLE, H.R., RODRIGUES, A.O. \& THULLIEZ, P.H. 1992. Prevalence of Toxoplasma gondii and Trichinella spiralis in 509 pigs from 31 farms in Oahu, Hawaii. Veterinary Parasitology, 43:57-63.

DUBEY, J.P., LEIGHTY, J.C., BEAL, V.C., ANDERSON, W.R., ANDREWS, C.D. \& THULLIEZ, P.H. 1991. National seroprevalence of Toxoplasma gondii in pigs. Journal of Parasitology, 77:517-521.

DUBEY, J.P. ROLLOR, E.A., SMITH, K., KWOK, O.C.H. \& THULLIEZ, P. 1997. Low seroprevalences of Toxoplasma gondii in feral pigs from a remote island lacking cats. Journal of Parasitology, 83:839-841.

DUBEY, J.P., THULLIEZ, P. \& POWELL, E.C. 1995. Toxoplasma gondii in lowa sows: comparison of antibody titers to isolation of $T$. gondii by bioassay in mice and cats. Journal of Parasitology, 81:48-53.

EDELHOFER, R. 1994. Prevalence of antibodies against Toxoplasma gondii in pigs in Austria-an evaluation of data from 1982 and 1992. Parasitology Research, 80:642-644.

HOVE, T. \& DUBEY, J.P. 1999. Prevalence of Toxoplasma gondii antibodies in sera of domestic and some wild game species from Zimbabwe. Journal of Parasitology, 85:372373.

JENSEN, L., PETERSEN, E., HENRIKSEN, S.A., DIETZ, H.H. \& LIND, P. 1998. Monoclonal antibodies to Toxoplasma gondii strain 119 identify recently isolated Danish strains as one group. International Journal for Parasitology, 28:1305-1313.

LIND, P., HAUGEGAARD, J., HEISEL, C., WINGSTRAND, A. \& HENRIKSEN, S.A. 1994. Seroprevalence studies of Toxoplasma gondii in Danish pig populations. Proceedings of the Baltic-Scandinavian Symposium on Parasitic Zoonoses and the Ecology of parasites. Vilnius, Lithuania. Bulletin of the Scandinavian Society of Parasitology, 5:15-16.

LIND, P., HAUGEGAARD, J., WINGSTRAND, A. \& HENRIKSEN, S.A. 1997. The time course of specific antibody response by various ELISAs in pigs experimentally infected with Toxoplasma gondii. Veterinary Parasitology, 71:1-15.

LUBROTH, J.S., DREESEN, D.D. \& RIDENHOUR, R.A. 1983. The role of rodents and other wildlife in the epidemiology of swine toxoplasmosis. Preventive Veterinary Medicine, 1: 169-178.

LUNDÉN, A., LIND, P., OLSSON-ENGVAL, E., GUSTAVSSON, K., UGGLA, A. \& VÅGSHOLM, I. 2002. Serological survey of Toxoplasma gondii infection in pigs slaughtered in Sweden. Scandinavian Journal of Infectious Diseases, 34:362-365.

PANDEY, V.S. \& VAN KNAPEN, V. 1992. The seroprevalence of toxoplasmosis in sheep, goats and pigs in Zimbabwe. Annals of Tropical Medicine and Hygiene, 86:313-315.

PARMELY, S.F., SGARLATO, G.D., MARK, J., PINCE, J.B. \& REMINGTON, J.S. 1992. Expression, characterization and serological reactivity of recombinant surface antigen P22 of Toxoplasma gondii. Journal of Clinical Microbiology, 30: 1127-1133.

PETTERSEN, E.K. 1977. Experimental toxoplasmosis in mice and rabbits. Acta Pathologica et Microbiologica Scandinavica Section $B, 85: 92-102$.

SABIN, A.B. 1941. Toxoplasmic encephalitis in children. Journal of the American Medical Association, 115:801-808.

SMITH, K.E., ZIMMERMAN, J.J., PATTON, S., BERAN, G.W. \& HILL, H.T. 1992. The epidemiology of toxoplasmosis in lowa swine farms with an emphasis on the roles of free-living mammals. Veterinary Parasitology, 42:199-211.

VAN KNAPEN, V., FRANCHIMONT, J.H. \& VAN DER LUGT, G. 1982. Prevalence of antibodies to Toxoplasma in farm animals in the Netherlands and its implication for meat inspection. Veterinary Quartely, 4:101-105.

VAN KNAPEN, F., KREMERS, A.F., FRANCHIMONT, J.H. \& NARUCKA, U. 1995. Prevalence of antibodies to Toxoplasma gondii in cattle and swine in the Netherlands: towards an integrated control of livestock production. Veterinary Quarterly, 17:87-91.

WEIGEL, R.M., DUBEY, J.P., SIEGEL, A.M., KITRON, U.D., MANNELLI, A., MITCHELL, M.A., MATEUS-PINILLA, N.E., THULLIEZ, P., SHEN, S.K., KWOK, O.C.H. \& TODD, K.S. 1995. Risk factors for the transmission of Toxoplasma gondii on swine farms in Illinois. Journal of Parasitology, 81:736741.

WINGSTRAND, A., LIND, P., HAUGEGAARD, J., HENRIKSEN, SV. A.A., BILLE-HANSEN, V. \& SØRENSEN, V. 1997. Clinical observations, pathology, bioassay in mice and serological response at slaughter in pigs experimentally infected with Toxoplasma gondii. Veterinary Parasitology, 72:129-140.

WORK, K.L. 1968. Resistance of Toxoplasma gondii encysted in pork. Acta Pathologica et Microbiologica Scandinavica, 73: 85-92. 